\title{
Knowledge of Obstructive Sleep Apnea Syndrome in the Society: Are Patients with Obstructive Sleep Apnea Syndrome Aware of Their IIIness?
}

\section{Toplumda Obstrüktif Uyku Apne Sendromu Konusunda Bilgi Düzeyi: Obstrüktif Uyku Apne Sendromu Olanlar Hastalıklarının Farkında mı?}

\author{
(D) Buket Tuğan Yıldız, (D) Deniz Tuncel Berktaş, (D) Kevser Işık*, (D) Ayşegül Erdoğan** \\ Kahramanmaraş Sütçü Imam University Faculty of Medicine, Department of Neurology, Kahramanmaraş, Turkey \\ *Kahramanmaraş Sütçü Imam University Faculty of Health Sciences, Department of Public Health Nursing, Kahramanmaraş, Turkey \\ **Kahramanmaraş Sütçü Imam University Faculty of Medicine, Department of Public Health, Kahramanmaraş, Turkey
}

\begin{abstract}
Objective: The prevalence of obstructive sleep apnea syndrome (OSAS) has increased in recent years. Despite these high prevalence rates, it is suggested that actual prevalence is even higher, because of the very low awareness about the disease and many cases of OSAS were not diagnosed. This study aimed to determine awareness about OSAS.

Materials and Methods: A face-to-face survey was conducted to individuals who sought to primary health care services. Participants were asked to complete the STOP-BANG questionnaire, a screening test for diagnosis of OSAS.

Results: A total of 293 participants completed the survey. Of these, $39.6 \%$ stated that they had heard about the disorder, but when asked to describe the disease, this rate dropped to $28.7 \%$. Only $20.5 \%$ could respond adequately. The STOP-BANG questionnaire was administered to the study group. Of the 293 patients, 194 (66.2\%) were diagnosed with low risk, 31 (10.6\%) had moderate risk and 68 (23.2\%) had high risk of OSAS. Based on the results of STOP-BANG questionnaire survey, $52(24.9 \%)$ patients who stated that they had no information about the disorder had a high risk of OSAS and $23(11 \%)$ had a moderate risk of OSAS.

Conclusion: Patients at risk of developing OSAS should be monitored by polysomnography and receive appropriate treatment. However, owing to the lack of knowledge, these patients are deprived of necessary treatment and thus become more susceptible to complications such as impaired concentration, hypertension, cardiac diseases, cerebrovascular diseases and even death.
\end{abstract}

Keywords: Obstructive sleep apnea syndrome, awareness, knowledge, public health

\section{Öz}

Amaç: Obstrüktif uyku apne sendromu (OUAS) prevalansı son yıllarda artmıştır. Bu yüksek prevelans oranlarına rağmen gerçek prevalansın daha yüksek olduğu ileri sürülmektedir çünkü hastalığın farkındalığı çok düşüktür ve bu nedenle şikayeti olan birçok hastaya OUAS tanısı konulamamaktadır. Bu çalışmada OUAS ile ilgili farkındalığı belirlemeyi amaçladık.

Gereç ve Yöntem: Aile hekimliği merkezlerine başvuran hastalara OUAS farkındalığı, bilgi düzeyiyle ilgili yüzyüze anket uygulandı. Aynı zamanda, katılımcılara OUAS tanısı için tarama testi olan STOP-BANG anketi uygulandı.

Bulgular: Iki yüz doksan üç katılımcı anketi tamamladı. Hastaların \%39,6'sı hastalığı duyduğunu belirtmişti ancak hastalığın ne olduğunu bilip bilmediği sorulduğunda bu oran \%28,7'ye düştü. Tüm hastaların yalnızca \%20,5'i tarif edebildi. STOP-BANG anketi çalışma grubunda uygulandı. İki yüz doksan hastadan 194'ü $(\% 66,2)$ düşük riskli, 31'i $(\% 10,6)$ orta riskli ve $\left.68^{\prime} i \mathrm{i} \% 23,2\right)$ yüksek OUAS riskine sahipti. STOPBANG anketinin sonuçlarına göre, OUAS hakkında bilgisi olmadığını belirten hastaların 52 'si $(\% 24,9)$ yüksek OUAS riski ve 23 'ü $(\% 11)$ orta derecede OUAS riskine sahipti.

Sonuç: OUAS semptomu olan hastalara polisomnografi yapılmalı ve tedavi başlanmalıdır. Ancak bu hastalar, OUAS konusunda bilgi sahibi olmadığından, tedaviden mahrum kalmakta ve konsantrasyon güçlüğü, hipertansiyon, kardiyak hastalıklar, serebrovasküler hastalıklar ve hatta ölüm gibi komplikasyonlar gelişebilmektedir.

Anahtar Kelimeler: Obstrüktif uyku apne sendromu, farkındalık, bilgi düzeyi, toplum sağlığı 


\section{Introduction}

Obstructive sleep apnea syndrome (OSAS) is the collapse of the upper airways which result in oxygen desaturation and repeated awakening during sleep (1). OSAS can cause neurocognitive disorders, excessive daytime sleepiness, depression, as well as cardiovascular and metabolic diseases such as hypertension, stroke and diabetes $(2,3)$. Although the first reports about this disease date back to the $18^{\text {th }}$ century, it has not attracted much attention until the 1970s (4).

The sleep heart health study (2002) has reported mild OSAS in at least $24 \%$ of men and $9 \%$ of women (5). In the Wisconsin sleep cohort study conducted in 2013, the prevalence of moderate to severe OSAS has been reported as $10 \%$ among males aged between 30-49, 17\% among males aged between $50-70$, 3\% among females aged between 30-49, and 9\% among females aged between 50-70 years (6).

In HypnoLaus study conducted in 2015, the prevalence of moderate to severe OSAS ( $\geq 15$ events per hour) has been reported as $23.4 \%$ in women and $49.7 \%$ in men (7). The prevalence of OSAS has been increased in recent years. Our hypothesis is that despite these high prevalence rates, it is suggested that the real prevalence is higher and due to low level of knowledge and awareness about the disorder, many people cannot be diagnosed with OSAS. Therefore, we conducted a survey in primary health care services in our city to determine the level of knowledge and awareness about OSAS.

\section{Materials and Methods}

The study was designed as a prospective, cross-sectional and it was approved by the Kahramanmaraş Sütçü İmam University Institutional Ethics Committee with study reference number 08/20.03.2019. In order to determine the OSAS awareness and level of knowledge, a face-to-face survey was conducted to the people who admitted to primary health care services, and the questions asked are shown in Table 1. At the same time, the participants were asked to complete the STOP-BANG questionnaire, a screening test for diagnosis of OSAS (Table 2). In addition, the data about the patients' age, gender, height, weight, neck size, information on their chronic diseases (if any), smoking and/or use of alcohol and phone number were recorded. Body mass indexes (BMI) and neck circumferences of all patients were determined by the same researcher. BMI was calculated as body weight $(\mathrm{kg})$ divided by squared height $\left(\mathrm{m}^{2}\right)$. Neck circumference was measured in the standing upright position, the measuring tape was placed midway around the neck, between the mid-cervical spine (C3) and mid anterior neck, below the level of thyroid gland (8).

The data was recorded in the SPSS statistics program. The sample population was derived from a group of consecutive patients who applied to primary health care services in 3-months period. Individuals under the age of 18 , those who refused to participate in the survey and those with serious neuropsychiatric diseases such as dementia and cognitive disorder were excluded from the study.

\section{Statistical Analysis}

All statistical analyses were performed using the SPSS version 21.0 program (SPSS Inc., Chicago, IL, USA). Descriptive analyses were based on frequencies and percentages for categorical variables and mean \pm standard deviation (SD) or median for continuous variables. The Kolmogorov-Smirnov test and histogram analysis were used to assess the distribution of the data. If the data were normally distributed, they are presented as mean \pm SD; when abnormally distributed, we report the median of the values. Spearman's correlation analysis

\begin{tabular}{|l|l|l|}
\hline \multicolumn{3}{|l|}{ Table 1. Survey questions asked to determine OSAS awareness } \\
\hline Education: (School completed) & Yes & No \\
\hline Do you smoke? & Yes & No \\
\hline Do you drink alcohol? & Yes & No \\
\hline Do you have a known chronic disease? & Yes & No \\
\hline Have you heard of sleep apnea syndrome? & Yes & No \\
\hline Do you know what sleep apnea is? & Yes & No \\
\hline Do you know which department is interested? & Yes & No \\
\hline Do you know what are the symptoms? & Yes & No \\
\hline Have you ever had a test for sleep apnea? & Yes & No \\
\hline Have you ever been diagnosed with sleep apnea? & Yes & No \\
\hline $\begin{array}{l}\text { Have you ever been treated with positive airway } \\
\text { pressure (CPAP or BiPAP)? }\end{array}$ & Yes & No \\
\hline Do you know that it can cause high blood pressure? & Yes & No \\
\hline Do you know that it can cause heart disease? & Yes & No \\
\hline Do you know that it can cause stroke? & & \\
\hline $\begin{array}{l}\text { OSAS: Obstructive sleep apnea syndrome, CPAP: Continuous positive airway } \\
\text { pressure, BiPAP: Bilevel positive airway pressure }\end{array}$ & & \\
\hline
\end{tabular}

Table 2. STOP-BANG questionnaire

(S) Snore? Are you snoring loudly? (causing loudness to be heard after closed doors or causing the person you shared the bed to nudge you with his elbow because you snore at night) Yes/No

(T) Tiredness? Do you often feel tired, exhausted or sleepy during the day? (such as falling asleep while driving)

Yes/No

(O) Observation? Did anyone observe that you stopped breathing or your throat was obstructed/breathless during your sleep?

Yes/No

(P) Blood pressure? Do you have high blood pressure or are you being treated for it?

Yes/No

(B) Is the body mass index more than $35 \mathrm{~kg} / \mathrm{m}^{2}$ ? Yes/No

(A) Is the age more than 50 ?

Yes/No

(N) Is the neck size wide? (measured around the Adam's apple) For men, is your shirt collar 17 inches $/ 43 \mathrm{~cm}$ or larger? For women, is your shirt collar 16 inches $/ 41 \mathrm{~cm}$ or wider? Yes/No

(G) Gender = male?

Yes/No 
was used to evaluate the association between education level and the number of correct answers. $\mathrm{P}<0.05$ was considered statistically significant.

\section{Results}

\section{Socio-demographic characteristics of the participants}

Two hundred-ninety three participants completed the survey. The mean age of the participants was $39.6 \pm 15.9$, the BMI was $27.3 \pm 5.4 \mathrm{~kg} / \mathrm{m}^{2}$, and the neck size was $37 \pm 4.5 \mathrm{~cm}$. Other sociodemographic characteristics are summarized in Table 3.

The answers given by the participants to the questions asked about OSAS awareness

The number of those who heard the diagnosis of sleep apnea syndrome was 116 (39.6\%). The number/rate of those who had never heard before was higher (177/60.4\%). When asked what OSAS is, this rate decreased further, dropping to 28.7 . Likewise, the percentage of those who know which department interested with this disease, what the symptoms were quite low (14\%, 20.5\%, respectively).

It is seen in the answers that the partipicants' level of knowledge about OSAS complications is also insufficient. Only 48 (16.4\%) participants know OSAS can cause high blood pressure, 53 (18.1\%) know OSAS can cause heart disease, 48 (16.4\%) know it can cause stroke. The answers given by the participants are summarized in Table 4. Participants' responses to the STOPBANG questionnaire summarized in Table 5.

\section{Discussion}

Despite the high prevalence rates of OSAS, it has been suggested that there are many patients who are not diagnosed with the disorder as the population's level of knowledge is quite low and this causes low number of cases diagnosed with OSAS. According to The Singapore Health 2 study, 1.306 people

\begin{tabular}{|l|l|}
\hline \multicolumn{2}{|l|}{ Table 3. Socio-demographic characteristics of the participants } \\
\hline & $\mathrm{N} / \%$ \\
\hline Gender & \\
Female & $179 / 61.1$ \\
Male & $114 / 38.9$ \\
\hline Education status & \\
Not literate & $36 / 12.3$ \\
Primary school graduate & $95 / 32.4$ \\
Secondary school graduate & $43 / 14.7$ \\
High school graduate & $59 / 20.1$ \\
Graduated from a university & $60 / 20.5$ \\
\hline Smoking & \\
Yes & $63 / 21.5$ \\
No & $230 / 78.5$ \\
\hline Alcohol use & \\
Yes & $8 / 2.7$ \\
No & $285 / 97.3$ \\
\hline Presence of chronic disease & \\
Yes & $101 / 34.5$ \\
No & $192 / 65.5$ \\
\hline
\end{tabular}

have been included in a telephone survey and 281 (21.5\%) respondents have declared that they had information on OSAS, but among them only 170 (13\%) participants were able to describe the disease correctly (2).

Arous et al. (9) have conducted a survey on OSAS awareness in 1.307 people living in the Lorraine region of France and have found that $67 \%$ of the participants knew most of the symptoms, but the level of knowledge was low in terms of neurological and cardiac complications. It has been reported that educated people and those younger than 40 years of age had a higher level of knowledge about the disorder (9).

Despite the fact that the awareness on OSAS is low and there are many undiagnosed patients, the number of studies conducted on this subject is low. In Turkey, there is only one survey conducted in Konya province of Turkey which has included 1.651 patients to determine the awareness on OSAS. In this study, $61 \%$ of the participants have reported that they had never heard of the OSAS before, 39\% had heard it, but

\begin{tabular}{|l|l|}
\hline \multicolumn{2}{|l|}{ Table 4. Answers given by the participants to the questions about } \\
OSAS awareness & N/\% \\
\hline \multicolumn{2}{|l|}{ Have you heard of sleep apnea syndrome? } \\
Yes & $116 / 39.6$ \\
No & $177 / 60.4$ \\
\hline Do you know what sleep apnea syndrome is? & \\
Yes & $84 / 28.7$ \\
No & $209 / 71.3$ \\
\hline Do you know which department is interested? & \\
Yes & $41 / 14$ \\
No & $252 / 86$ \\
\hline Do you know what are the symptoms? & \\
Yes & $60 / 20.5$ \\
No & $233 / 79.5$ \\
\hline Have you had a test for sleep apnea syndrome? & \\
Yes & $8 / 2.7$ \\
No & $285 / 97.3$ \\
\hline Have you ever been diagnosed with sleep apnea & \\
syndrome? & \\
Yes & $2 / 0.7$ \\
No & $291 / 99.3$ \\
\hline Have you ever been treated with positive airway & \\
pressure for OSAS (CPAP/BiPAP)? & \\
Yes & $2 / 0.7$ \\
No & $291 / 99.3$ \\
\hline Do you know that it can cause high blood pressure? & \\
Yes & $48 / 16.4$ \\
No & $245 / 83.6$ \\
\hline Do you know that it can cause heart disease? & \\
Yes & $53 / 18.1$ \\
No & $240 / 81.9$ \\
\hline Do you know that it can cause stroke? & \\
Yes & \\
No & \\
\hline CPAP: Continuous positive airway pressure, BiPAP: Bilevel positive airway \\
pressure, OSAS: Obstructive sleep appnea syndrome
\end{tabular}


only $11.9 \%$ have reported that they had sufficient knowledge about the disorder. It has been shown that women, patients older than 30 years of age and those with a higher education had a better level of knowledge about the disorder. When the results were examined in terms of the symptoms, it has been demonstrated that snoring and sleep respiratory pauses were normal situations for $13.2 \%$ and $7.9 \%$ of the participants, respectively and $16.8 \%$ and $8.1 \%$ participants had no idea about snoring and sleep respiratory pauses. Moreover, $14 \%$ of the participants knew that OSAS could lead to hypertension, $20.1 \%$ to heart failure, $39.7 \%$ to sudden death in sleep, $29.8 \%$ to rhythm disorder, and $7.3 \%$ to diabetes mellitus (10).

Our study is the second study conducted to determine the awareness of the population in Turkey. Only $2.7 \%$ of our participants have been tested for OSAS before, and $0.7 \%$ have been diagnosed with OSAS. In our study, similar to the results of Şentürk et al. (10) and The Singapore Health 2 studies, 39.6\% of the patients stated that they had heard about the disorder, but when they were asked to describe the disease, this rate dropped to $28.7 \%$. When the patients were asked to describe the symptoms, the rate decreased further, and only $20.5 \%$ could respond adequately. It is clear that only a small portion of the society knows about the OSAS symptoms, and the number of participants who know which hospital department to admit when these symptoms arise is quite low (14\%). Our results

\begin{tabular}{|l|l|}
\hline \multicolumn{2}{|l|}{$\begin{array}{l}\text { Table 5. Answers given by the participants to the STOP-BANG } \\
\text { questionnaire }\end{array}$} \\
\hline \multicolumn{2}{|l|}{ N/\% } \\
\hline $\begin{array}{l}\text { Are you snoring loudly? } \\
\text { Yes }\end{array}$ & $115 / 39.2$ \\
No & $178 / 60.8$ \\
\hline Do you often feel tired, exhausted or sleepy & \\
during the day? & \\
Yes & $162 / 55.3$ \\
No & $131 / 44.7$ \\
\hline Is it observed that you stop breathing while & \\
sleeping? & \\
Yes & $42 / 14.3$ \\
No & $251 / 85.6$ \\
\hline Do you have high blood pressure? Are you being & \\
treated for this? & \\
Yes & $52 / 17.7$ \\
No & $241 / 82.3$ \\
\hline Is the body mass index more than 35 kg/m²? & \\
Yes & $44 / 15$ \\
No & $249 / 85$ \\
\hline Is your age over 50? & \\
Yes & $66 / 22.5$ \\
No & $227 / 77.5$ \\
\hline Is the neck size wide? & \\
Yes & $32 / 10.9$ \\
No & $261 / 89$ \\
\hline Is gender male? & \\
Yes & $113 / 38.6$ \\
No & $180 / 61.4$ \\
\hline
\end{tabular}

show that the patients do not have sufficient information on the disorder, the level of knowledge about the symptoms is low and even if they notice the symptoms, they do not know which department to admit. Thus, diagnosis and treatment are delayed and the risk of developing complications increases.

After we examined the level of knowledge about the disorder, we also examined the level of awareness about complications. While the prevalence of hypertension has been found as high as $30-70 \%(11)$ and the rate of major cardiac and cardiovascular diseases in 3 years has been found as $18.9 \%(12,13)$ in patients with OSAS, the awareness on hypertension, heart disease, and cerebral palsy was $16.4 \%, 18.1,16.4 \%$, respectively. The level of awareness on complications was found similar to the study of Şentürk et al. (10).

We conducted a screening test using the STOP-BANG questionnaire in the study group and aimed to roughly determine the prevalence of OSAS. The STOP-BANG questionnaire in the Turkish population was validated by Acar et al. (14). In this study, of the 293 patients, 194 (66.2\%) was diagnosed with low risk, 31 (10.6\%) had moderate risk and 68 (23.2\%) had high risk of OSAS. Based on the results of STOP-BANG questionnaire, $52(24.9 \%)$ of the patients who stated that they had no information on disorder, had a high risk of OSAS and $23(11 \%)$ had a moderate risk of OSAS. When the patients are at risk of developing OSAS, they should be monitored with polysomnography and receive treatment for the disorder. However, due to lack of knowledge, these patients are deprived of necessary treatment and they become more susceptible to experience complications such as concentration impairment, hypertension, cardiac diseases, cerebrovascular diseases and even death.

\section{Study Limitations}

In this study, our aim is point out the low knowlegde about OSAS. Altough STOP-BANG is a good screening tool, it does not replace polisomnography. For determination of true prevelance of disease polysomnography should be used.

\section{Conclusion}

We found a low level of OSAS awareness similar to other studies. Unlike other studies, we found a high risk of OSAS due to STOPBANG questionnaire in patients who did not have sufficient information about the disorder. Thus, we demonstrated that there are many patients who are likely to have OSAS, but have not been diagnosed with OSAS and have not received any treatment. The awareness should be raised in society and people should be informed about the symptoms of the disorder and where to go if they think they have OSAS.

The public's awareness of this disease and its treatment will also contribute significantly to public health by reducing the prevalence of many chronic diseases that are complicated by this disease such as cardiovascular diseases.

\section{Ethics}

Ethics Committee Approval: All procedures performed in human participants in this study were in accordance with the ethical standards of the institutional and/or national research 
committee and with the 1964 Helsinki Declaration and its later amendments or comparable ethical standards. Kahramanmaraş Sütçü İmam University Institutional Ethics Committee approval was obtained vide study reference number 08/20.03.2019.

Informed Consent: Written informed consent was obtained from all individual participants included in the study.

Peer-review: Internally peer-reviewed.

\section{Authorship Contributions}

Design: B.T.Y., D.T.B., K.I., A.E., Data Collection or Processing: B.T.Y., D.T.B., K.I., A.E., Writing: B.T.Y., D.T.B., K.I., A.E.

Conflict of Interest: No conflict of interest was declared by the authors.

Financial Disclosure: The authors declared that this study received no financial support.

\section{References}

1. Rundo JV. Obstructive sleep apnea basics. Cleve Clin J Med 2019;86(9 Suppl 1):2-9.

2. Sia $\mathrm{CH}$, Hong Y, Tan LWL, van Dam RM, Lee $\mathrm{CH}$, Tan A. Awareness and knowledge of obstructive sleep apnea among the general population. Sleep Med 2017;36:10-7.

3. Jordan AS, McSharry DG, Malhotra A. Adult obstructive sleep apnoea. Lancet 2014;383:736-47.

4. Guilleminault C, Tilkian A, Dement WC. The sleep apnea syndromes. Annu Rev Med 1976;27:465-84.

5. Young T, Shahar E, Nieto FJ, Redline $S$, Newman AB, Gottlieb DJ, Walsleben JA, Finn L, Enright P, Samet JM; Sleep Heart Health Study Research Group. Predictors of sleep-disordered breathing in community-dwelling adults: the Sleep Heart Health Study. Arch Intern Med 2002;162:893-900.
6. Peppard PE, Young $\mathrm{T}$, Barnet $\mathrm{JH}$, Palta $\mathrm{M}$, Hagen EW, Hla KM. Increased prevalence of sleep-disordered breathing in adults. Am J Epidemiol 2013;177:1006-14.

7. Heinzer R, Vat S, Marques-Vidal P, Marti-Soler H, Andries D, Tobback N, Mooser V, Preisig M, Malhotra A, Waeber G, Vollenweider P, Tafti M, Haba-Rubio J. Prevalence of sleep-disordered breathing in the general population: the HypnoLaus study. Lancet Respir Med 2015;3:310-8.

8. Tom C, Roy B, Vig R, Kang DW, Aysola RS, Woo MA, Harper RM, Kumar R. Correlations between waist and neck circumferences and obstructive sleep apnea characteristics. Sleep Vigil 2018;2:111-8.

9. Arous F, Boivin JM, Chaouat A, Rumeau C, Jankowski R, Nguyen DT. Awareness of obstructive sleep apnea-hypopnea syndrome among the general population of the Lorraine Region of France. Eur Ann Otorhinolaryngol Head Neck Dis 2017;134:303-8.

10. Şentürk $H$, Eryilmaz MA, Vatansev $H$, Pekgör S. Evaluation of knowledge level related to obstructive sleep apnea syndrome. Niger J Clin Pract 2019;22:1722-7.

11. Silverberg DS, Oksenberg A. Are sleep-related breathing disorders important contributing factors to the production of essential hypertension? Curr Hypertens Rep 2001;3:209-15.

12. Dredla BK, Castillo PR. Cardiovascular consequences of obstructive sleep Apnea. Curr Cardiol Rep 2019;21:137.

13. Lee $C H$, Sethi R, Li R, Ho HH, Hein T, Jim MH, Loo G, Koo CY, Gao XF, Chandra S, Yang XX, Furlan SF, Ge Z, Mundhekar A, Zhang WW, Uchoa CHG, Kharwar RB, Chan PF, Chen SL, Chan MY, Richards AM, Tan HC, Ong TH, Roldan G, tai BC, Drager LF, Zhang JJ. Obstructive sleep apnea and cardiovascular events after percutaneous coronary intervention. Circulation 2016;133:2008-17.

14. Acar HV, Kaya A, Yücel F, Erdem M, Günal SE Özgen F, Dikmen B. Validation of the STOP-Bang questionnaire: an obstructive sleep apnoea screening tool in Turkish population. Turk J Anaesth Reanim 2013;41:115-20. 